\title{
PECULIARITIES OF MORPHOGENESIS OF CHANGES IN THE PERIODONTIUM AT EXPERIMENTAL ACTION OF OPIOID DURING TWO WEEKS AND ITS SUBSEQUENT FOUR WEEKS CANCELLATION AND CORRECTION
}

\author{
Fik V. B., PhD in Anatomy, Assoc. Professor, Department of Normal Anatomy, Danylo Halytskyy
}

Lviv National Medical University, Lviv, Ukraine,

ORCID ID: https://orcid.org/0000-0002-2284-4488

Mota O. M., PhD in Anatomy, Assoc. Professor, Department of Normal Anatomy, Danylo Halytskyy

Lviv National Medical University, Lviv, Ukraine,

ORCID ID: https://orcid.org/0000-0003-4516-1169

Halyuk U. M., PhD in Anatomy, Assoc. Professor, Department of Normal Anatomy, Danylo

Halytskyy Lviv National Medical University, Lviv, Ukraine,

ORCID ID: https://orcid.org/0000-0002-9974-2156

Pal'tov Ye. V., PhD in Anatomy, Assoc. Professor, Department of Normal Anatomy, Danylo Halytskyy Lviv National Medical University, Lviv, Ukraine, ORCID ID: https://orcid.org/0000-0002-2622-4753

DOI: https://doi.org/10.31435/rsglobal_sr/30062020/7136

\section{ARTICLE INFO}

Received 10 April 2020

Accepted 03 June 2020

Published 30 June 2020

\section{KEYWORDS}

periodontium, opioid, drug correction, rats, microscopic examination.

\begin{abstract}
The aim of the study was to examine the periodontal tissues of white rats under two weeks of opioid exposure, after its abolition and drug correction for four weeks at the optical level. After two weeks of experimental action of the opioid analgesic and its subsequent four-week withdrawal, pronounced irreversible changes in the structural components of the periodontium of animals were not detected, however, and their complete recovery was not observed. The proposed drug correction with pentoxifylline and ceftriaxone with opioid withdrawal after two weeks of its administration, led to the restoration of microcirculation and trophic tissues of periodontal tissues of rats, their morphological organization was approaching normal.
\end{abstract}

Citation: Fik V. B., Mota O. M., Halyuk U. M., Pal'tov Ye. V. (2020) Peculiarities of Morphogenesis of Changes in The Periodontium at Experimental Action of Opioid During Two Weeks and Its Subsequent Four Weeks Cancellation and Correction. Science Review. 5(32). doi: 10.31435/rsglobal_sr/30062020/7136

Copyright: (C) 2020 Fik V. B., Mota O. M., Halyuk U. M., Pal'tov Ye. V. This is an open-access article distributed under the terms of the Creative Commons Attribution License (CC BY). The use, distribution or reproduction in other forums is permitted, provided the original author(s) or licensor are credited and that the original publication in this journal is cited, in accordance with accepted academic practice. No use, distribution or reproduction is permitted which does not comply with these terms.

The results of the article correspond to the research plan of Lviv National Medical University named after Danylo Halytsky and are part of the research topic of the Department of Normal Anatomy "Morpho-functional features of organs in the pre- and postnatal periods of ontogenesis, under the influence of opioids, food additives, reconstructive surgery and obesity", state registration number 0120 U002129.

Decreasing of resistance of the mucous membrane of the gingiva under the action of various pathogenic factors leads to the development of diseases of the oral cavity, parodontal tissues, which is one of the most actual problems in modern dentistry $[1,2,3,8,10]$. The connection between the occurrence and nature of oral diseases with drug use is undeniable today [5]. Despite the importancy of the problem, in the current professional literature there are isolated studies that highlight only some 
aspects of the clinical picture in the parodontium in opioid-addicted persons [6]. The data about condition of the oral cavity organs and tissues during drug withdrawal are extremely important [11, 12], since the analysis of changes in soft tissues of parodontium at drug addiction should contribute to the development of adequate treatment measures [2,7]. In this aspect, the pathogenetically substantiated medicine pentoxifylline, which is used in case of microcirculation disorders, also has antioxidant and anti-inflammatory effects [9]. In addition, at the presence of various associations of pathogenic microflora in dental-gingival pockets, it is important to search for effective antimicrobial medicines $[1,4]$. However, in the professional literature we have not found data about the features of structural changes in parodontium affected by opioid analgesic and correction of these changes through its abolition or using of medicines.

The aim was to investigate the biopsy specimens of rats' parodontal tissues at a two-weeks period of opioid exposure, after its cancellation and medicamental correction during four weeks at the light-optic level.

\section{Materials and methods.}

White outbred male rats (34) with an average weight of $200 \mathrm{~g}$, age 4.5 months, were used as the research material. The experimental animals were divided into 3 groups. The first group included intact rats (10). In the second group animals (12) during first two weeks were administered intramuscularly opioid analgesic nalbuphine, based on the average therapeutic dose for rats $0.212 \mathrm{mg} /$ $\mathrm{kg}$, followed with opioid withdrawal. In the third group, rats (12) received injections of nalbuphine for 14 days $(0.212 \mathrm{mg} / \mathrm{kg})$ and discontinuation of the drug use for the next 28 days. Pentoxifylline and the antibiotic ceftriaxone were used to correct pathological changes in the parodontium resulting from the action of the opioid. The pentoxifylline was injected intramuscularly at the same time interval $(2,857 \mathrm{mg} / \mathrm{kg})$ during 28 days after opioid withdrawal. Injections of ceftriaxone were given once during 11 days at the end of the experiment $\left(5^{\text {th }}-6^{\text {th }}\right.$ week $)$ at a dose equivalent for rat $-2.86 \mathrm{mg} / \mathrm{kg}$. The material was collected six weeks after the experiment. Animals were kept under standard vivarium conditions and all experiments were carried out in accordance with the provisions of the "European Convention for the Protection of Vertebrate Animals Used for Experimental and Other Scientific Purposes" [Strasbourg, 1985] and according to the decision of the Danylo Halytskyy Lviv National Medical University (Protocol No 5 of May 25, 2012). The material for the microscopic examination were the amputated upper jaws and exarticulated mandibles, taking into account the preservation of the topographic correlation of the tissues of the dental organ, making histological sections with a thickness of 5-7 microns. Previously, complex decalcification of jaw fragments in $18 \%$ hydrochloric acid solution at $20^{\circ} \mathrm{C}$ during four days was performed. Preparations for lightoptical examination were prepared according to the conventional method using the pigments of hematoxylin, eosin and azan by the Heidenhein method.

\section{Results and discussion.}

Microscopic studies performed six weeks after the experiment in the second group of animals, conditioned with the introduction of nalbuphine for two weeks and its subsequent four-weeks withdrawal showed that there were slight degenerative changes in the structural components of the parodontium, however, less expressed in intensity than in animals with six weeks of opioid administration. In the histological sections, the thickness of the epithelial lining of the mucous membrane of the gingiva in the vast majority of animals was of uneven thickness. In places, the stratified squamous epithelium was well structured, differentiation of cell layers was preserved. Signs of orthokeratosis were visualized. The stratum corneum in such cases was continuous, with moderate exfoliation of the stratum corneum. However, in large areas there was a thickening of the epithelial layer with an increase and compaction of the stratum corneum, the phenomenon of hyperkeratosis. Epithelial growths were mostly short, pointed, however, in some places were absent (Fig. 1). In some areas there were signs of dyskeratosis, which was manifested by a violation of the keratinization of epitheliocytes, the formation of round formations and diffuse stratification of the stratum corneum.

The epithelial layer of the gingival sulcus was moderately compacted, with signs of focal proliferation of deep layers into the lamina propria of the mucous membrane of the gingiva. In the area of the bottom of the sulcus there is an injry of the connective part with partial preservation of fixation of the epithelial conjunction to the enamel-cement border of the tooth (Fig. 2). The revealed signs indicate about the presence of reactive changes in the epithelial layer of the mucous membrane of gingiva with a background of the two-weeks action of the opioid and its cancellation. 


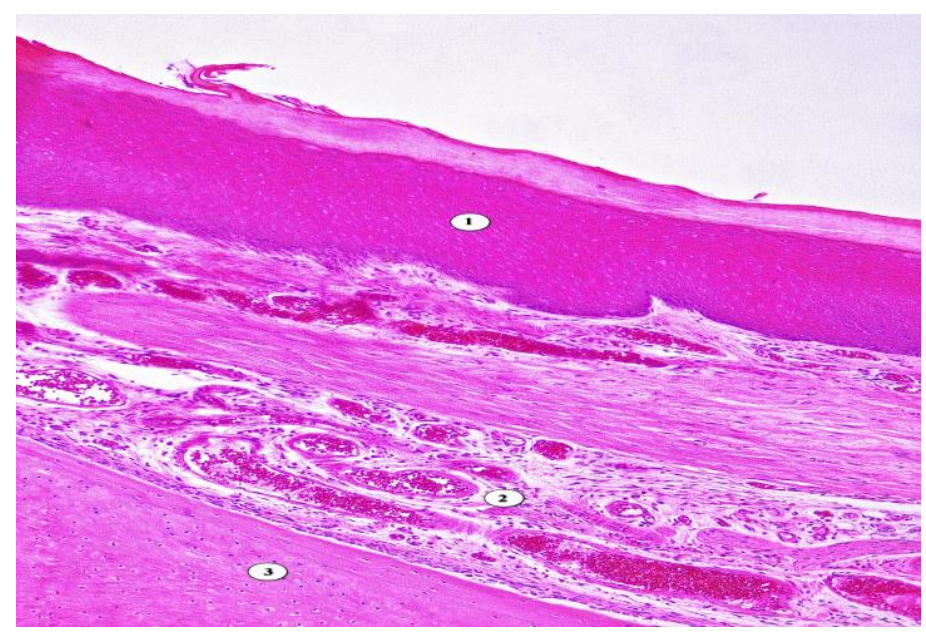

Fig. 1. Microscopic organization of tissues of the periodontium of the rat after six weeks: two weeksopioid, four weeks after its cancellation. Coloring with hematoxylin and eosin. Approx. x 100. 1 moderate hyperkeratosis; 2 -multiple angiomatosis, aggregation of erythrocytes in the lumen of blood vessels, 3 - bone tissue.

In the lamina propria of the mucous membrane of the gingiva revealed minor violations of the architecture of collagen fibers and moderate perivascular edema of the intercellular substance. In the papillary and reticular layers of the lamina propria there are lymphohistiocytic infiltrates of small size, connective tissue papillas are elongated, however, in large areas they are smoothed or absent (Fig. 1-2).

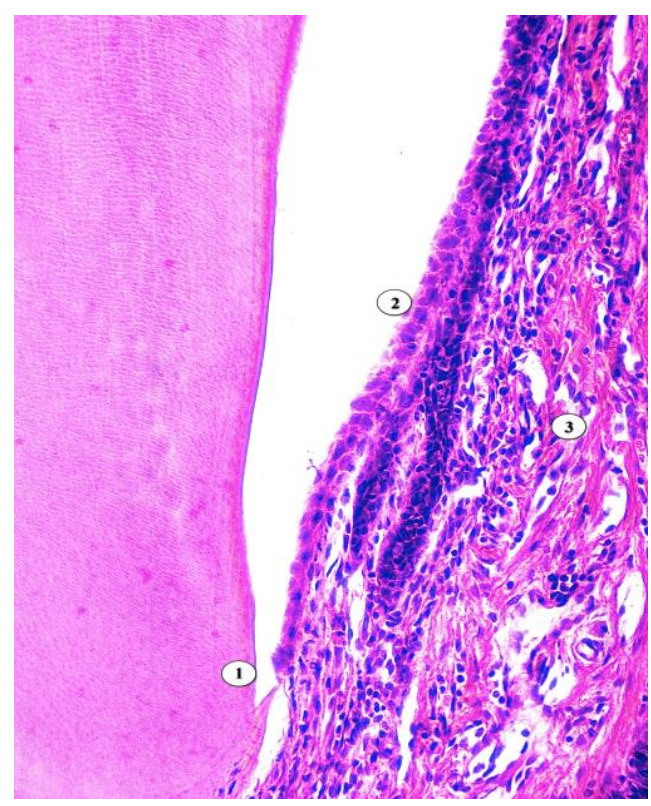

Fig. 2. Microscopic organization of tissues of the periodontium of the rat after six weeks: two weeks opioid, four weeks after its cancellation. Coloring with hematoxylin and eosin. Approx. $x 100$.

1 -epithelial conjunction, 2 - epithelium of the gingiva sulcus, 3 -polymorphic-cellular infiltration.

Vessels of the hemomicrocirculatory channel are with moderate blood filling, however, showed signs of edema of vascular walls, their plethora, angiomatosis, stasis, aggregation of erythrocytes in the lumen of blood vessels, as well as focal hemorrhages of diapedesal nature (Fig. 1).

We did not find any pronounced deep changes in the connective tissue of the periodontium, we noted the integrity of the fibers of the circular ligament of the marginal periodontium. Moderate infiltration and numerous fibroblasts were observed in the dense connective tissue of the periodontium. However, in the middle third of the periodontium there was a fragmentary stratification of collagen fibers, the phenomenon of moderate edema. The vessels of the periodontium were mostly without visible changes, vessels of moderate filling, however, there were local areas of focal hemorrhage of diapedetic nature (Fig. 4). The bone tissue of the alveolar processus is diffusely 
homogeneous, in small areas the lines of adhesion are determined (Fig. 1). Destructive changes in the periosteum and root cementum of the tooth have not been detected.

Thus, the detected changes in this group were manifested by thickening of the epithelium, hyperkeratosis and dyskeratosis, damage to the epithelial attachment, destruction of collagen fibers, edema and vascular disorders in the connective tissue, which indicated the residual effects of the inflammatory process.

Histological studies in the third experimental group under the condition of two-week administration of the opioid, its subsequent withdrawal within four weeks and medical correction showed that the microscopic organization of periodontal tissues has a positive dynamics, morphological picture of the structural components of parodontium is close to normal.

In the multilayered flat epithelium of the free and attached parts of the gingiva the stratification of the layers of cells is preserved, the epitheliocytes are clearly differentiated. Microscopically in the epithelium of the free part of the gingiva there was a slight consolidation, clearly visualized orthokeratosis. The horn squama formed a continuous layer, the surface of the desquamation of the horny squama of the surface layer of the epithelial plate was moderate. In some places the basal layer was unevenly smoothed, the baseal membrane was clearly visible. Epithelial growths are moderately expressed, mostly of normal shape and length, slightly rounded, no signs of acanthosis were observed.

No destructive changes were observed in the epithelial plate of the dental-gingival sulcus. The sulcular section of the epithelium was clearly and evenly contoured, in the absence of damage and detachment of the surface layer of the epithelial plate. As a result of complex drug correction with pentoxifylline and ceftriaxone, there were signs of regeneration of the epithelial cover of the dentalgingival sulcus, which was accompanied by an increase in the number of lymphocytes in the spiky layer and mitotic cell dividing in the basal layer (Fig. 3). The epithelial conjunction is without signs of destruction, visualized a clear fixation to the enamel-cement border of the tooth, which accordingly determined the integrity and safety of the bottom of the gingival sulcus, preventing the dissemination of microflora into the underlying tissues of the periodontium.

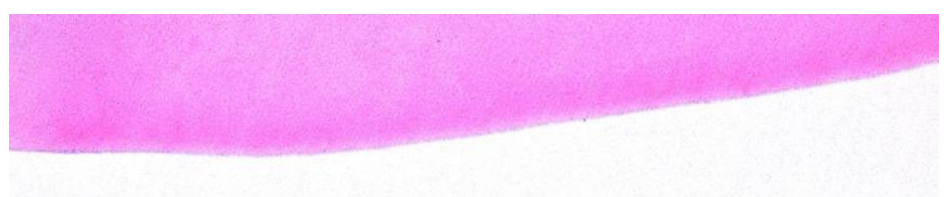

(2)

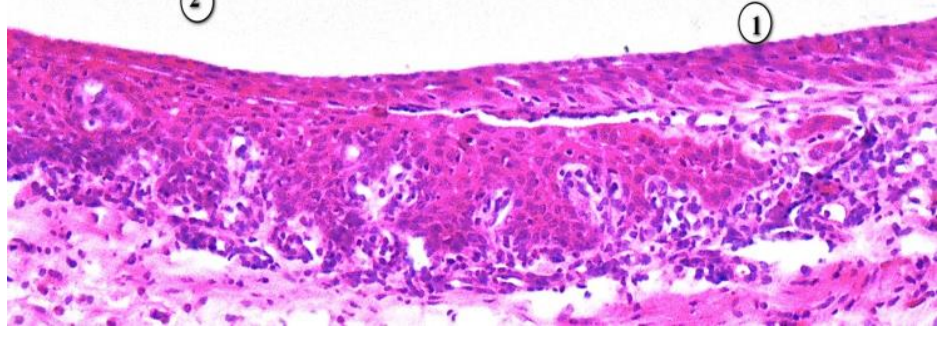

Fig. 3. Microscopic organization of tissues of the periodontium of the rat after six weeks: two weeks opioid, four weeks after its cancellation and correction with pentoxifylline and ceftriaxone. Coloring with hematoxylin and eosin. Approx. x 400. 1 - regeneration of the sulcular epithelium; 2 - dentalgingival sulcus.

No destructive changes were detected in the lamina propria of the mucous membrane of the gingiva. The architectonics of collagen fibers was preserved, fibroblasts are structurally unchanged, somewhat elongated, which was within normal limits. In the papillary and reticular layers of the the lamina propria of the mucous membrane of the gingiva pronounced edema was not observed, in places polymorphonuclear infiltration was determined. The connective tissue papillae were mostly short, homogeneous, visually normal in size, some places well defined. The vessels were mostly moderately blood-filled, the vessel wall was not damaged, there were no signs of edema of the vessel walls, dilatation and hemorrhage. After the treatment, recovery of the components of the hemomicrocirculatory tract was also noted. 
In the connective tissue of the mucous membrane of the gingival observed in the phenomena of angiogenesis, numerous capillary buds.

The structural organization of the connective tissue of the periodontium was also normalized and practically did not differ from the animals of the intact group (Fig. 4). The bundles of collagen fibers of the tooth neck region in the upper third of the periodontium had a circular direction, retained their structure. The circular ligament was intact, which is an important factor in maintaining the integrity of the bottom of the dental-gingival sulcus. The intercellular substance is homogeneous, collagen fibers are structured. The infiltration of connective tissue is moderately expressed, with a predominance of fibroblasts in their composition. Hemomicrocirculatory tract of the periodontium without pronounced changes, vessels of larger diameter were localized in the area of the apical periodontium, compared with a smaller diameter in the cervical region. Hemomicrovascular of moderate blood supply, their walls did not thicken, signs of dilatation and angiomatosis were not observed (Fig. 4). The bone tissue is diffusely homogeneous, the layers of periosteum without visible changes, with the localization of numerous osteoblasts, cell-free and cellular cement without significant changes (Fig. 4).

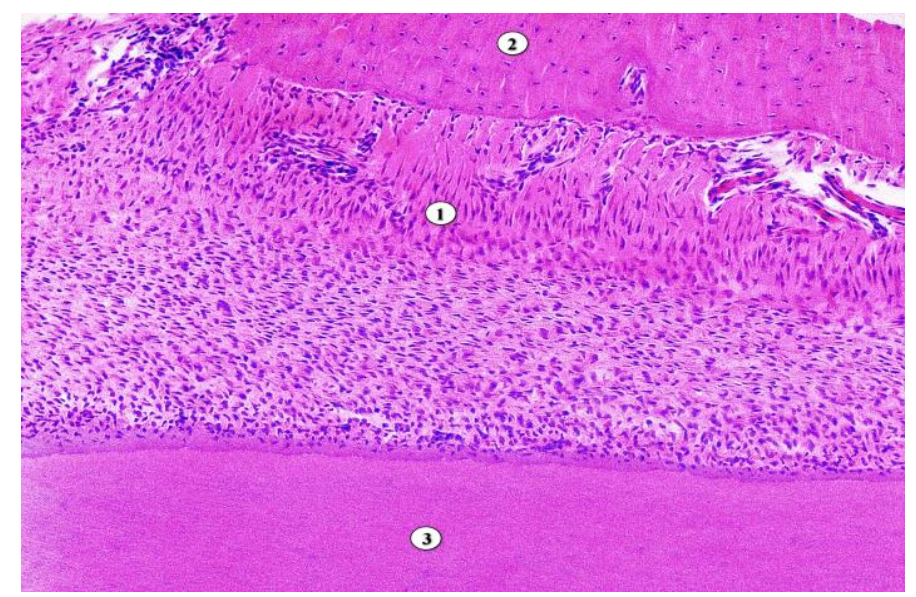

Fig. 4. Microscopic organization of tissues of the periodontium of rat after six weeks: two weeks opioid, four weeks after its cancellation and correction with pentoxifylline and ceftriaxone. Coloring with hematoxylin and eosin. Approx. x 100. 1 - periodontium, 2 - bone tissue, 3 - tooth root cementum.

Thus, the complex use of pentoxifylline and ceftriaxone in the long-term withdrawal of opioids revealed a positive dynamics of structural reorganization of the periodontal components of animals. The morphological organization of gum epithelial cells, which approached the epitheliocytes of intact animals in terms of layer structure and stratification, was significantly improved. Discomplexation of epitheliocyte layers in large areas was absent. The phenomena of epithelial plate regeneration were observed in the gingival sulcus. The integrity of the epithelial attachment determined the preservation of the bottom of the gingival sulcus. The connective tissue was dominated by signs of the usual ratio of intercellular structures and cell composition. The main substance was homogeneous, collagen fibers are clearly structured, no signs of edema were observed. Vessels of a hemomicrocirculatory channel of a connecting fabric were moderately blood-filled, the phenomena of angiogenesis were noted.

According to available professional sources, narcotic drugs abuse directly affects the genesis and progression of diseases of the organs and tissues of the oral cavity $[2,6,11,12]$. Taking into account that there are signs of dystrophic and inflammatory process at the development of periodontal diseases, it is important to use a pathogenetic corrective influence using antihypoxic or antibacterial agents $[3,4,8]$. The results of our research show that the long term period of opioid withdrawal and complex correction with pentoxifylline and ceftriaxone have a positive effect on the structural organization of parodontal tissues. It was not possible to carry out a detailed analysis of the comparison of the obtained data, since in the professional literature there are absent experimental researches about the introduction of nalbuphine in average therapeutic doses, followed by the corrective effect of pathological changes that are developed on the background of the short-term opioid influence. 
Conclusions. 1. After two weeks of experimental action of the opioid analgesic and its subsequent four-week withdrawal, no pronounced irreversible changes in the structural components of the periodontium were detected.

2. However, long-term withdrawal of opioids in the second group of animals did not lead to complete restoration of periodontal structures, the dynamics of compensatory-adaptive reactions was somewhat slowed down, which may create preconditions for recurrence of the pathological process.

3. In the third group of animals it was found that the use of pentoxifylline and ceftriaxone in the abolition of opioid analgesic after two weeks of its introduction, led to improved structuring of the epithelium and connective tissue of the periodontium, their morphological organization was approaching normal.

4. The proposed complex drug correction contributed to the restoration of microcirculation and periodontal tissue trophism, which indicated the active involvement in the process of compensatory-adaptive reactions.

\section{REFERENCES}

1. Ісакова Н.М. Вплив дентальної вкладки на стан мікрофлори пародонтальних кишень у пацієнтів 3 генералізованим пародонтитом / Н.М. Ісакова, П.А. Ісаков, О.С. Киніна, Т.Р. Закалата // Вісник морфології. 2016; 2(22): 332-35.

2. Костенко Є.Я. Аналіз змін стоматологічного статусу в пацієнтів з наркотичною залежністю / Є.Я. Костенко, А.І. Форос // Современная стоматология. 2016; 2: 120-123.

3. Кузенко Є.В. Особливості патогенезу та морфогенезу запальних захворювань пародонта. Автореферат дис. докт. мед. наук. Харків: Харківський національний медичний університет; 2017. 42 с.

4. Матвійків T.I. Ультраструктурні зміни епітелію ясен хворих на генералізований пародонтит в динаміці терапії / Т.І. Матвійків // Хірургія Донбасу. 2017; 2: 40-44.

5. Соколова I.І. Особливості надання стоматологічної допомоги та професійного спілкування 3 хворими на наркоманію / І.І. Соколова, Н.М. Соколова, Н.М. Савельєва // Клінічна стоматологія. 2015; 2: 77-82.

6. Токмакова С.И. Особенности стоматологического статуса больных опийной наркоманией / С.И. Токмакова. Ю.В. Луницына // Дальневосточный медицинский журнал. 2014; 1: 130-135.

7. Фік В.Б. Електронномікроскопічні дослідження пародонту при шеститижневому впливі та його відміні упродовж чотирьох тижнів в експерименті /В.Б. Фік, С.В. Пальтов// Abstracts of III International Scientific and Practical Conference Liverpool, United Kingdom. 2019. 392-399.

8. Manji, F. Caries and periodontitis: contesting the conventional wisdom on their aetiology / F. Manji, G. Dahlen, J. Fejerskov // Caries Res. 2018; 52 (6): 548-564.

9. McCarty M.F. Pentoxifylline for vascular health: a brief review of the literature / M.F. McCarty, J.Y. O’Keefe, J.J. DiNicolantonio // Open Heart. 2016; 3: e000365. doi: 10.1136/openhrt-2015-000365.

10. Nazir M.A. Prevalence of periodontal disease, its association with systemic diseases and prevention / M.A. Nazir // In J Health Sci (Qassim). 2017; 11 (2). - P. 72-80.

11. Sevarino K. Medically supervised opioid withdrawal during treatment for addiction/K. Sevarino, A.J. Saxon, R. Hermann // In: Post TW, editor. UpToDate [Internet]. Waltham (MA): UpToDate; 2018 [cited 2018 Jan 30]. Available from: www.uptodate.com.

12. Shekarchizadeh H. Oral health behavior of drug addicts in withdrawal treatment/H. Shekarchizadeh, M.R. Khami, S.Z. Mohebbi, J.I. Virtanen // BMC Oral Health. 2013; 13: 11. 